\title{
Perinatal Outcome and Multidisciplinary Management
}

\section{Stefania Erra}

Department of Surgical Pathology, Santo Spirito Hospital, Casale Monferrato, Italy

*Corresponding author: Stefania Erra, Department of Surgical Pathology, Santo Spirito Hospital, Casale Monferrato, Italy, E-mail: stefania.erra@virgilio.it

Received date: September 29, 2017; Accepted date: October 03, 2017; Published date: October 13, 2017

Copyright: (c) 2017 Erra S. This is an open-access article distributed under the terms of the Creative Commons Attribution License, which permits unrestricted use, distribution, and reproduction in any medium, provided the original author and source are credited.

\section{Introduction}

Perinatal deaths are unpleasant events involving the obstetrics team and, sometimes, pathologists when autopsy is required.

In Italy, there isn't a uniform approach towards these events. In some referral hospitals, internal agreement has been established between medical specialties involved in the management of perinatal mortality. In little provincial hospital, there aren't recognized guidelines. To improve the government of these events, in our hospital a multidisciplinary team has been identified able to face the problems inherent cases of perinatal death.

\section{Materials and Methods}

In the last ten years, numerous motifs regarding incorrect management of perinatal mortality have led to the need to build a multidisciplinary process. For this reason, pathologists organized a training event on perinatal death, finalized to establish roles and responsibilities of each health profession involved in this event.

As result of our course, a document has been prepared in which every task was established. This document has been approved by responsible of the single medical specialties and finally shared by the hospital management officially.

\section{Results}

A flow chart has been prepared to face perinatal death events correctly. This proposal has been accepted from multidisciplinary team. It has been synthesized in the Table 1 .

Second our agreed division of roles, every health specialized doctor knows what to do, when and how to do it in a correct way, with saving of time and resources and with a real benefit for the parents.

\section{Discussion}

Management of perinatal death is difficult, above all in absence of agreed guidelines. After the practical need for a more effective management of issues, a medical multidisciplinary team decided to define local simple guidelines, finalized to have a medical record for all cases of perinatal death.

The document identifies specific roles for each specialized doctor, in order to objectify and standardize procedures and methods and to give a real benefit to parents. Systematical study of problems related to perinatal mortality is facilitated by orderly and methodical data collection, guaranteed by a unique method of procedure [1]

In this context, our medical team identified a diagnostic, therapeutic and welfare route (PDTA) regarding the management of perinatal death [1]. In the reported guidelines pathologists have a central role, not only for the material organization of the route, but helping to introduce methods of diagnostic imaging little used in perinatal autopsy [2]. In fact TC-virtopsy is used in legal autopsy, without a concrete pathological finding, in absence of collaboration through pathologists and radiologists.

\begin{tabular}{|c|c|}
\hline EVENT/PROTAGONIST & OBJECT/ROLES \\
\hline $\begin{array}{l}\text { Perinatal death (from } 21 \text { weeks }+5 \text { days of } \\
\text { intauterine life to one month after birth) }\end{array}$ & Medical record \\
\hline \multirow{6}{*}{ Obstetrical team } & Anamnestic history \\
\hline & Contact neonatologist \\
\hline & Microbiological samples \\
\hline & $\begin{array}{l}\text { Request autopsy after parenta } \\
\text { consent }\end{array}$ \\
\hline & $\begin{array}{l}\text { Request histological evaluation of } \\
\text { placenta (intrauterine death) }\end{array}$ \\
\hline & Forms accepted and shared \\
\hline \multirow{3}{*}{ Neonatologist } & $\begin{array}{l}\text { Opening and compilation of } \\
\text { medical record }\end{array}$ \\
\hline & $\begin{array}{l}\text { Samples of blood (Guthrie test) } \\
\text { and tissue (molecular tests) }\end{array}$ \\
\hline & External exam \\
\hline \multirow{5}{*}{ Pathologists } & $\begin{array}{l}\text { Perinatal autopsy according to } \\
\text { APEFA guidelines }\end{array}$ \\
\hline & $\begin{array}{l}\text { Photos and evaluation indices of } \\
\text { growth and maturation }\end{array}$ \\
\hline & $\begin{array}{l}\text { Ancillary imaging studies } \\
\text { (radiographs and virtopsy) }\end{array}$ \\
\hline & $\begin{array}{l}\text { Placental histological evaluation in } \\
\text { case of intrauterine death }\end{array}$ \\
\hline & $\begin{array}{l}\text { Transmission of the histologica } \\
\text { reports to gynecology and } \\
\text { pediatrics }\end{array}$ \\
\hline \multirow{3}{*}{ Radiologist } & Ancillary instrumental exams: \\
\hline & $\begin{array}{l}\text { Radiograph for } \quad \text { osseous } \\
\text { morphologic alterations }\end{array}$ \\
\hline & Virtopsy with TC system \\
\hline
\end{tabular}

Table 1: Flow chart has been prepared to face perinatal death events correctly. 
Page 2 of 2

In our work-team, the presence of radiologists experienced in virtopsy and pathologists interested in perinatal pathology has made possible a real collaboration between the two medical specialties.

\section{Conclusion}

Perinatal death represents a very important adverse event. In fact, it becomes a serious mourning for parents and a loss of professional esteem for the involved operator. As with the diagnosis and treatment of neoplasms, perinatal pathology has to be faced scientifically and systematically by identifying accepted and shared guidelines.

Results of the multidisciplinary team interaction are a more rapid and reliable work, a greater attention during autopsy by pathologists, guided from the virtopsy feedback [3]. Finally parents longer feel protected and reassured from the existence of a multidisciplinary specialized team prepared to study and understand the motifs of their baby death.

\section{References}

1. McPherson E, Nestoridi E, Heinke D, Roberts DJ, Fretts R, et al. (2017) Alternatives to Autopsy for Fetal and Early Neonatal (Perinatal) Deaths: Insights from the Wisconsin Stillbirth Service Program. Birth Defects Res. Doi: $10.1002 / \mathrm{bdr} 2.1112$

2. Badam RK, Sownetha T, Babu DBG, Waghray S, Reddy L, et al. (2017) Virtopsy: Touch-free autopsy. J Forensic Dent Sci 9:42. Doi: 10.4103/ jfo.jfds_7_16

3. Nijkamp JW, Sebire NJ, Bouman K, Korteweg FJ, Erwich JJHM, et al. (2017) Perinatal death investigations: What is current practice? Semin Fetal neonatal Med 22:167-175. Doi: 10.1016/j.siny.2017.02.005. 